
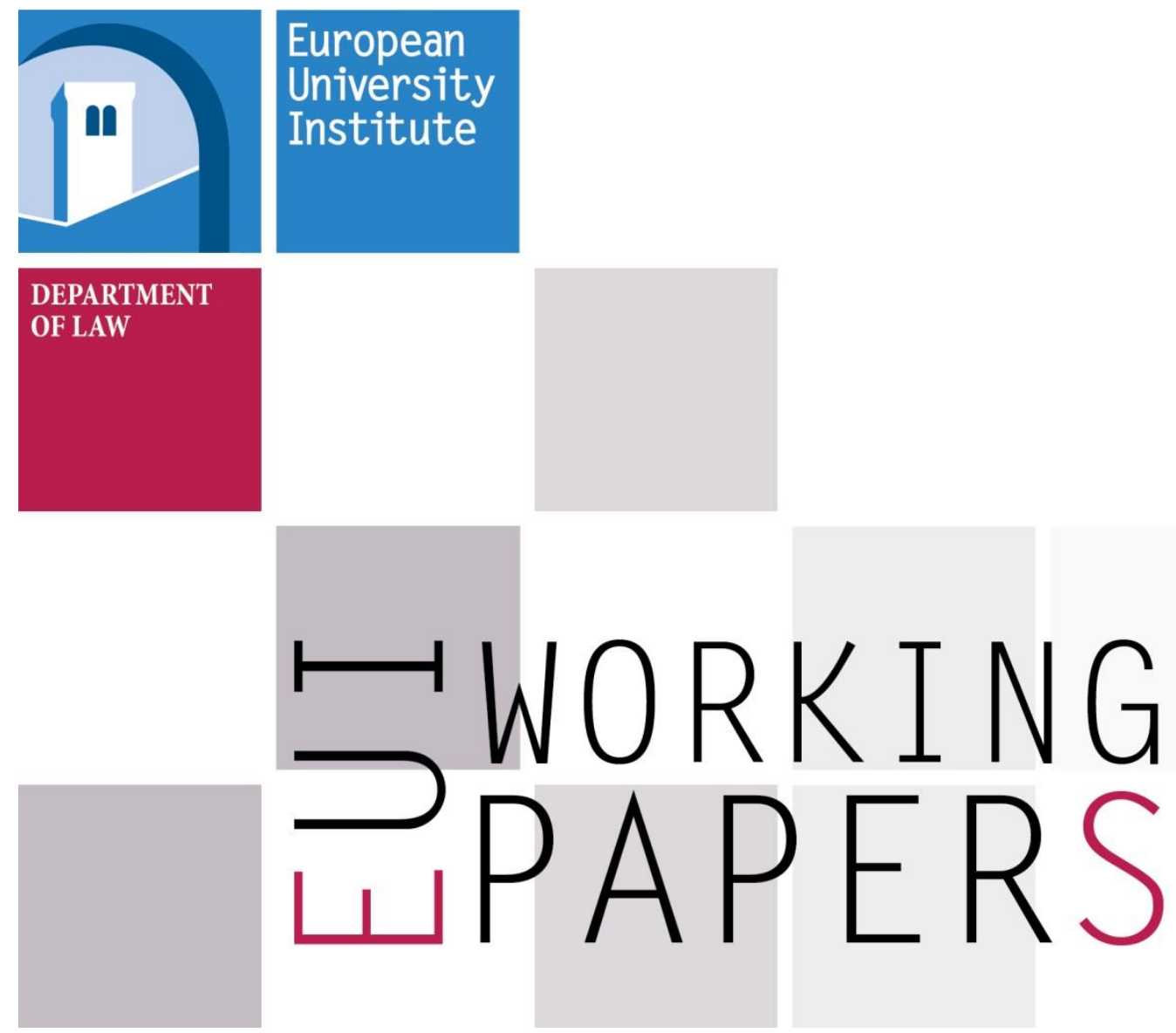

LAW 2015/14

Department of Law

Legal Manifestations of the Emergency in National Euro Crisis Law

Stephen Coutts, Leticia Díez Sánchez, Afroditi Marketou and Leonardo Pierdominici 

European University Institute

Department of Law

\section{LEgal MANifeStations OF THE EMERGENCY in National EURo Crisis LAW}

Stephen Coutts, Leticia Díez Sánchez, Afroditi Marketou and Leonardo Pierdominici

EUI Working Paper LAW 2015/14 
This text may be downloaded for personal research purposes only. Any additional reproduction for other purposes, whether in hard copy or electronically, requires the consent of the author(s), editor(s). If cited or quoted, reference should be made to the full name of the author(s), editor(s), the title, the working paper or other series, the year, and the publisher.

ISSN 1725-6739

(C) Stephen Coutts, Leticia Díez Sánchez, Afroditi Marketou and Leonardo Pierdominici, 2015 Printed in Italy

European University Institute

Badia Fiesolana

I-50014 San Domenico di Fiesole (FI)

Italy

www.eui.eu

cadmus.eui.eu 


\section{Constitutional Change through Euro-Crisis Law}

This paper was first delivered at a conference held at the European University Institute in October 2014 presenting some initial results of the project on Constitutional Change through Euro Crisis Law. This project is a study of the impact of Euro Crisis Law (by which is meant the legal instruments adopted at European or international level in reaction to the Eurozone crisis) on the national legal and constitutional structures of the 28 Member States of the European Union with the aim of investigating the impact of Euro Crisis law on the constitutional balance of powers and the protection of fundamental and social rights at national level. An open-access research tool (eurocrisislaw.eui.eu) has been created, based on a set of reports for each Member State, that constitutes an excellent resource for further, especially comparative, studies of the legal status and implementation of Euro Crisis law at national level, the interactions between national legal systems and Euro Crisis law and the constitutional challenges that have been faced. The project is based at the EUI Law Department and is funded by the EUI Research Council (2013-2015). 



\section{Authors' contact details}

\section{Stephen Coutts}

$\mathrm{PhD}$ Researcher in Law

European University Institute

Law Department

Via Boccaccio 121

50133 Firenze, Italy

Stephen.Coutts@eui.eu

\section{Leticia Díez Sánchez}

$\mathrm{PhD}$ Researcher in Law

European University Institute

Law Department

Via Boccaccio 121

50133 Firenze, Italy

Leticia.Diez@eui.eu

\section{Afroditi-Ioanna Marketou}

$\mathrm{PhD}$ Researcher in Law

European University Institute

Law Department

Via Boccaccio 121

50133 Firenze, Italy

Afroditi-Ioanna Marketou@eui.eu

\section{Leonardo Pierdominici}

$\mathrm{PhD}$ Researcher in Law

European University Institute

Law Department

Via Boccaccio 121

50133 Firenze, Italy

Leonardo.Pierdominici@eui.eu 


\begin{abstract}
Most constitutions foresee a 'state of emergency' associated with the existence of an armed conflict. Paradoxically, modern societies seem to be permanently confronted with genuine emergencies increasingly removed from the threat of actual, physical violence. The Eurozone crisis can be said to have accentuated this, as the immense pressures from financial markets have turned the control of public finances into a struggle for the survival of the affected States. The present paper explores the legal manifestations of emergency in the domestic law of Greece, Italy, Spain and Ireland. These countries have all been hit by the Eurozone crisis (albeit in different manners) and have had to accommodate external oversight in their crisis management. The adoption of emergency measures for tackling the economic upheavals has been diverse across the case studies, although all have in common the emergence of a prominent role for the executive in the aftermath of the Eurozone crisis.
\end{abstract}

\title{
Keywords
}

Constitutional law, constitutional change, Eurozone crisis, economic emergency, emergency legislation 


\section{Table of Contents}

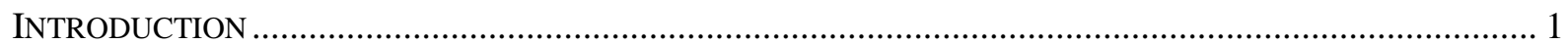

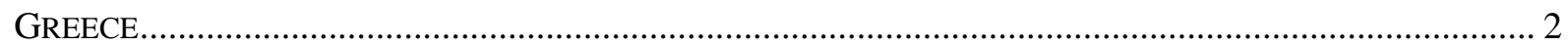

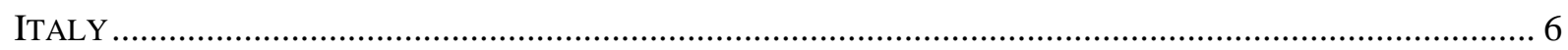

SPAIN

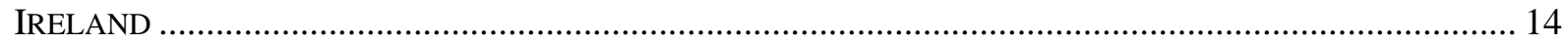

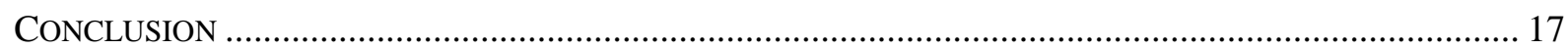





\section{Introduction}

In the social sciences the term 'emergency' (emergencia, emergenza, $\kappa \alpha \tau \varepsilon \pi \varepsilon i \gamma o v$ ) is used to indicate sudden situations of difficulty or danger which tend to be transient in nature (although not necessarily brief) and which involve a crisis of the institutions operating within a given social structure. ${ }^{1}$ In the legal discourse, the concept of 'state of emergency', alludes to circumstances of special gravity for a community that allow for the suspension or violation of all or certain legal dispositions in order to deal with an exceptional situation. ${ }^{2}$ Most constitutions foresee a 'state of emergency' associated with the existence of an armed conflict. Paradoxically, modern societies seem to be permanently confronted with genuine emergencies that are increasingly removed from the threat of actual, physical violence. ${ }^{3}$ As Scheuerman observes, "executive-dominated emergency economic regulation now represents a more or less permanent feature of political life in many liberal democracies." be said to have accentuated this, as the immense pressures from financial markets have turned the control of public finances into a struggle for the survival of the affected States. ${ }^{5}$

The present paper explores the legal manifestations of emergency in the domestic law of Greece, Italy, Spain and Ireland. These countries have all been hit by the Eurozone crisis (albeit in different manners) and had to accommodate external oversight in their crisis management. In May 2010 Greece agreed to a financial assistance programme of $€ 110$ billion with the IMF and the euro area Member States under strict conditions of reform of the national economy. Later, in July 2011 it received a further package of $€ 130$ billion through the $\mathrm{EFSF}^{6}$. Italy has not needed to resort to external financial assistance but instead has been the largest issuer of securities acquired by the European Central Bank within the Securities Market Programme. This acquisition was preceded by a letter from the European Central Bank requesting the President of the Italian Council of Ministers to undertake a number of reforms ${ }^{7}$. Spain, which received a similar letter from the ECB suggesting structural measures, ${ }^{8}$ received $€ 41.3$ billion from the ESM for the recapitalization of its banking sector. Lastly, Ireland entered into a programme of financial assistance of $€ 67.5$ billion with the IMF and the EU in November 2010, which it exited successfully in $2013^{9}$.

The adoption of emergency measures for tackling the economic upheavals has been diverse across the case studies, although all have common the emergence of a prominent role for the executive in the aftermath of the Eurozone crisis. Whereas in Greece, Spain and Italy emergency is primarily translated in the use of 'legislation of emergency' (Decree-laws and abbreviated parliamentary procedures), in Ireland it has been accommodated by ordinary legal concepts and procedures. Consideration of the exceptional nature of the situation have reached the courts as much as they have conditioned the

\footnotetext{
${ }^{1}$ According to the definition by A. Pizzorusso, Emergenza (Stato di), in Enciclopedia delle Scienze sociali, Roma, 1993, Istituto dell'Enciclopedia italiana, vol. III, ad vocem, pp. 551-559.

2 D Dyzenhaus, 'The Compulsion of Legality' in V V Ramraj (ed.) Emergencies and the Limits of Legality (2008), Cambridge and New York: CUP, p. 34.

${ }^{3}$ K Roach, 'Ordinary Laws for Emergencies and Democratic Derogations from Rights' in V V Ramraj (ibid.), pp. 229 - 230.

${ }^{4}$ W Scheuerman, ‘The Economic State of Emergency', 21 Cardozo L. Rev. (1999-2000), p. 1869, at 1870.

5 J White, 'Emergency Europe', Political Studies (forthcoming, first published online on 13 Sept 2013).

${ }^{6}$ See A I Marketou and M Dekastros Constitutional Change through Euro Crisis Law: Report of Greece available at http://eurocrisislaw.eui.eu/country/greece/, Section X 'Financial Support'.

7 See L Pierdominici Constitutional Change through Euro Crisis Law: Report of Italy, available at http://eurocrisislaw.eui.eu/country/italy/, Section X 'Financial Support'.

${ }^{8}$ See L Diez Sanchez, M Estrada Cañamares and G Gómez Ventura Constitutional Change through Euro Crisis Law: Report of Spain, available at http://eurocrisislaw.eui.eu/spain/, Section X 'Financial Support'.

9 See S Coutts, Constitutional Change through Euro Crisis Law: Report of Ireland, available at http://eurocrisislaw.eui.eu/ireland/, Section X 'Financial Support'.
} 
executive: only on few occasions have the Courts struck down euro crisis laws, ${ }^{10}$ and generally judges have explicitly acknowledged the pressing needs behind the measures.

\section{Greece}

Since the outburst of the eurocrisis, emergency has been the major justification for the significant constitutional changes that the country has been experiencing. Emergency discourse has been used to justify the content as well as the procedure followed for the implementation of crisis-related measures.

From this point of view, law $3845 / 2010^{11}$ has been a legal landmark. The particularity of this statute lies firstly in the substantial changes it brought about concerning austerity and social rights protection. Under the title "Measures for the implementation of the support mechanism for the Greek economy by the Eurozone MS and the IMF", the statute includes as an annex the Memorandum of Understanding (MoU) signed by the Greek Ministry of Finance and Greece's creditors, as well as relevant Statements by the Euro-area MS' Heads of State and Government. The policies announced in these texts are partly implemented in the main part of the statute. Article 3 imposes severe cuts on the revenues of public employees and pensioners. This article also affects employees with a private law contract and declares that it prevails over any contrary provision, be it part of a collective agreement, arbitral award or individual contract. Article 4 imposes consumer tax increases, while article 5 imposes an exceptional "social responsibility" levy on the profits of moral persons and a tax on TV advertisements. It is no exaggeration to say that law 3845/2010 is the legal event that divided the Greek society and political world into two camps: pro-memorandum and anti-memorandum forces.

As in the media, during the parliamentary discussion of the statute, economic emergency was invoked by Government to face the strong reactions to austerity. Left wing parties blamed the violation of social rights and acquis in order to serve the interests of the big capital holders and the country's creditors. They cited the report by the Scientific Service of the Parliament, expressing doubts as to the constitutionality of certain provisions in the statute. ${ }^{12}$ The Government in response claimed to have been taken by surprise by the gravity of the country's economic situation. Austerity measures were thus necessary and urgent. ${ }^{13}$ In the explanatory report accompanying the statute, the Government argued that the activation of the support mechanism and the onerous measures agreed in the MoU were an "action of responsibility and an historical obligation to face the danger of collapse of the Greek economy." "In the Government's view, the measures implemented were the only available response to the social, political and moral crisis that the country was facing. In the words of the introductory report annexed to the statute, the only alternative to these measures would be "collapse and destruction". ${ }^{15}$

This argumentation was translated in formal legal terms by the Council of State, when called to rule on the constitutionality of law $3845 .{ }^{16}$ The Court, reiterating the exceptional circumstances the country

\footnotetext{
${ }^{10}$ This has been changing lately in Greece, though. Cf. the report, Section X, para X.9 'Case Law Implementing Measures'.

${ }^{11}$ OJ 65 A'/6.5.2010. Cf. http://www.hellenicparliament.gr/Nomothetiko-Ergo/Anazitisi-Nomothetikou-Ergou?law_id=d7 ec2044-faa2-4a09-a9e8-cd0240b98bf5

${ }^{12}$ Cf. the report, available at http://www.hellenicparliament.gr/UserFiles/7b24652e-78eb-4807-9d68-e9a5d4576eff/m-dntepistimoniki.qxp.pdf

13 Cf. Minutes of the Greek Parliament on the $6^{\text {th }}$ of May 2010, available at http://www.hellenicparliament.gr/User Files/a08fc2dd-61a9-4a83-b09a-09f4c564609d/es20100506_1.pdf, p. 6714 f.

$14 \mathrm{Cf}$. the explanatory report, available at http://www.hellenicparliament.gr/UserFiles/2f026f42-950c-4efc-b950-340 c4fb76a24/M-DNTAMEIO-eis1.qxp.pdf, p. 1.

${ }^{15} \mathrm{Cf}$. the introductory report to the statute, available at http://www.hellenicparliament.gr/UserFiles/c8827c35-4399-4fbb8ea6-aebdc768f4f7/AOIKONOMIKVN.pdf, pp. 1-3.

${ }^{16}$ Cf. decision 668/2012, on the $20^{\text {th }}$ of February 2012.
} 
was facing, found that the impugned measures were justified by the compelling public interest of the consolidation of public finances, which also constituted the common interest of Eurozone MS. Until recently, the Court had constantly rejected the nature of a "fiscal interest of the State" as a legitimate reason justifying fundamental rights' restrictions. However, since the beginning of the crisis, the path to decision 668/2012 had been paved by the Court in previous cases: the financial public interest had been progressively qualified as a "compelling national interest". ${ }^{17}$ Thus, in decision 668/2012, deferring to governmental policy choices, the administrative judges stated that no examination of lessrestrictive alternatives was required, since the impugned measures were part of a general programme for facing the economic crisis.

The crisis left no place for parliamentary discussion on the policies pursued in the statute or on the specific measures enacted. Despite its historical importance, law 3845 was brought to Parliament under the emergency procedure. The Government repeatedly stated that its voting was urgent, in order for the relevant loan agreement to be concluded before the 19th of May. On this date, a $€ 10 \mathrm{bn}$ bond loan matured and, if the country was unable to repay its creditors, it would face bankruptcy and isolation from its Eurozone partners. The representative of the Government repeatedly compared the situation of the country to a state of war. ${ }^{18}$ Deputies had less than 3 days to read the statute and its annexes, and only one day to discuss it in Parliament. Even members of the Government later admitted that they had not had the time to read the MoU. The support mechanism and the measures it implied were approved as a whole in one single article, rendering any amendments to specific austerity provisions contained in the MoU's 80 pages impossible. Strict party discipline was imposed on the members of the two biggest parties in Parliament. Errors in the Greek translation of the MoU further poisoned the national debate. The marginal role of Parliament and the lack of information provoked strong reactions by opposing parties. Against procedural objections raised by left wing parties, the Government appealed to a "democratic and national responsibility" to approve the statute. ${ }^{19}$

However, from a legal scholar's point of view, law 3845/2010 is even more impressive in formal terms, that is, as far as legal norm production is concerned. What was the Parliament actually doing when voting on the statute? Was the MoU an international agreement requiring ratification? Should it then be voted by a qualified majority as article 28 of the Constitution imposes in some cases? Or was it simply the political programme of the Government, attached to the statute as part of its explanatory report? These questions have raised important academic and judicial debates. ${ }^{20}$ In its first article, law 3845 contains a description of the steps taken for the constitution and activation of the support mechanism. In the introductory report to the draft law it is stated that the annexed MoU are an "integral part of the statute". ${ }^{21}$ The Council of State in its relevant decision found the MoU to be the political programme of the Government, which could not be submitted to judicial scrutiny. ${ }^{22}$ However, the Prime Minister had repeatedly stated in the relevant parliamentary debates that the MoU and the statute were not the Government's political choice but had been imposed by the creditors. ${ }^{23}$ In the public discourse of the Government, the fulfillment of the loan agreement conditions is perceived as a

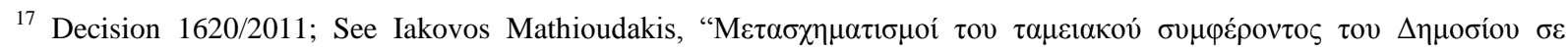

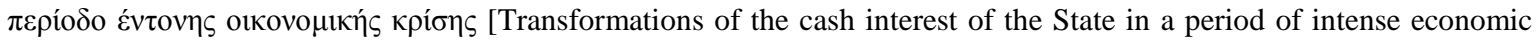
crisis]", www.constitutionalism.gr.

${ }^{18}$ Cf. Minutes of the Greek Parliament on the $6^{\text {th }}$ of May 2010, cited above, for example, p. 6728.

${ }^{19}$ Cf. Minutes of the Greek Parliament on the $6^{\text {th }}$ of May 2010, cited above, p. 6762.

${ }^{20}$ See the report on Greece, question X.3.

${ }^{21}$ Cf. the introductory report, cited above, p. 3.

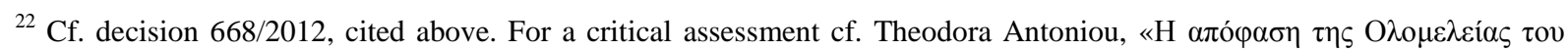

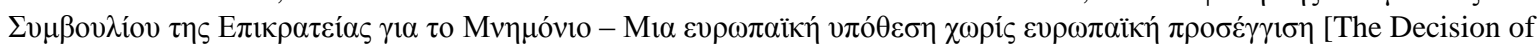
the Plenary Session of the Council of State on the Memorandum - A European Affair Lacking a European Approach]», $T o \Sigma 1$ [2012], p. 197.

${ }^{23}$ Cf. Minutes of the Greek Parliament on the $6^{\text {th }}$ of May 2010, cited above, p. 6766.
} 
binding obligation imposed on the country. Economic emergency, thus, dilutes constitutional forms and procedures and blurs the boundaries of national sovereignty.

Deconstruction of constitutional forms and procedures becomes permanent in the main body of the statute. Article 1, paragraph 4 delegates to the Minister of Finance the authority to sign future MoU and agreements for the application of the economic adjustment programme. However, it did provide that the relevant agreements must be brought to Parliament for ratification. This provision was amended two days later, again through the emergency procedure: the term "ratification" was replaced by the terms "discussion and briefing", rendering the relevant agreements operative from their signature. The amendment was necessary in order for the First Loan Agreement, signed some days later, to come into immediate effect, and thus before the $19^{\text {th }}$ of May. Further, article 2 of the statute confers a broad range of powers to the executive to take the necessary measures for the application of the economic adjustment programme. These provisions, far too broad to meet the commonly accepted limits to the delegation of legislative power set by the Greek Constitution, make emergency norm production a permanent possibility.

Law 3845/2010 marks the starting point of a serious degradation of constitutional democracy in Greece. Of course, even before the crisis, constitutional provisions were far from perfectly effective in practice. Still, the current decline is of a different kind, since it takes place at a symbolic level as well, manifesting itself in a substantial loss of faith by the legal, political and social community in the Constitution and the political conventions of the past.

This is obvious in the use of a twofold emergency rhetoric by Government, apparent in the justification of law 3845/2010. On the one hand, in many cases, the rhetoric of "exceptional circumstances" justifies measures connected to the eurocrisis. Following this line of argumentation, interference with individual rights is justified since under the exceptional circumstances the country is facing, individual interests are deemed to be outweighed by the public interest. This kind of emergency is therefore accommodated by the Constitution and affects the scope of its provisions, especially as far as fundamental social rights are concerned. Though exceptional, the situation remains within the constitutional realm, influencing the interpretation of constitutional norms. This argumentation also appears in the relevant decision by the Council of State; this is not surprising since this court derives its powers from the Constitution itself. In more recent cases, however, Greek courts have scrutinized more stringently the infringement of fundamental rights and have declared unconstitutional measures related to the economic adjustment programme. ${ }^{24}$

In other instances, the overall effect of the Constitution is challenged, since the Government goes further, employing a "war" or "political responsibility" rhetoric, in order to justify derogation from clear constitutional rules and procedures. Courts are incompetent faced with such a situation, since the interna corporis of the Parliament are traditionally immune from judicial scrutiny. This kind of discourse appears in the parliamentary discussion of the nature of the first MoU. When opposing parties objected in Parliament that, as a ratification of an international treaty, the statute 3845/2010 should be voted by a qualified majority, the Prime Minister at the time responded that, when voting for the MoU, the major concern should not be the qualified majority required by the Constitution, but the national and political responsibility of the Parliament and of its members towards the country and its creditors. ${ }^{25}$ In this and in other statements, governmental representatives draw the image of a state of

\footnotetext{
${ }^{24}$ See decision 1972/2012 by the Plenum of the Council of State; 4th Special Sitting of the Plenum of the Court of Audit on the 31 st of October 2012; decision 2192-6/2014 by the Plenum of the Council of State. See generally the report, Section X, para X.9 'Case Law Implementing Measures'.

${ }^{25}$ See Minutes of the Greek Parliament, $6^{\text {th }}$ of May 2010, cited above, p. 6762.
} 
exception, where constitutional norms do not apply. Still, they do not refer to article 48 of the Constitution on the "state of siege", the very strict conditions of which would not be met. ${ }^{26}$

The loss of faith in the Constitution is exemplified, moreover, in the serious degradation of the role of Parliament. Even before the crisis, it would be naïve to think of the Greek Parliament as a wellfunctioning representative legislator. However, since the application of the economic adjustment programme recommendations by the troika determine (or are claimed to do so) every aspect of governmental policy. It seems that the regime has shifted to a system whereby Parliament is impotent faced with an "executive unbound". ${ }^{27}$ As the examples above show, the legal and political accountability of the Government and the troika is negated due to a lack of transparency as to who takes the important policy decisions and whether these decisions are legally binding or not.

Moreover, no loan agreement has ever been ratified by Parliament, even though this is rendered obligatory by law voted by roughly the same persons who have transgressed it. ${ }^{28}$ For the Second Loan Agreement and its Amendments, the practice used to circumvent the ratification requirement would confuse the most cunning of constitutional lawyers: the Government issues an emergency decree-law, approving the draft of the relevant loan agreement and authorizing the competent authorities to sign it. Then, when agreements are already valid and operative as far as agreeing the parties are concerned, the relevant decree-laws are introduced into Parliament for ratification, which validates them retroactively. ${ }^{29}$

This is not the only example of Parliament being called upon only to ratify de facto established situations. Indeed, during the crisis governments have made increasingly extensive use of the

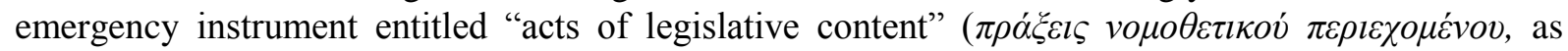
decree-laws are called in Greek). According to article 44 paragraph 1 of the Greek Constitution,

Under extraordinary circumstances of an urgent and unforeseeable need, the President of the Republic may, upon the proposal of the Cabinet, issue acts of legislative content. Such acts shall be submitted to Parliament for ratification, as specified in the provisions of article 72 paragraph 1, within forty days of their issuance or within forty days from the convocation of a parliamentary session. Should such acts not be submitted to Parliament within the above time-limits or if they should not be ratified by Parliament within three months of their submission, they will henceforth cease to be in force. ${ }^{30}$

Usually putting forward a formal, self-serving justification, ${ }^{31}$ governments use this sui generis instrument to implement complex and contentious provisions. This practice is even more degrading for the role of Parliament, if one considers that often many such administrative acts are subsequently

${ }^{26}$ This article could only be invoked "in case of war or mobilization owing to external dangers or an imminent threat against national security, as well as in case of an armed coup aiming to overthrow the democratic regime" Source of translation: http://www.hellenicparliament.gr/UserFiles/f3c70a23-7696-49db-9148-f24dce6a27c8/001-156\%20aggliko.pdf.

${ }^{27}$ See the relevant section in Lina Papadopoulou, “Can Constitutional Rules, Even if 'Golden', Tame Greek Public Debt?”, in Maurice Adams, Federico Fabbrini and Pierre Larouche (eds), The Constitutionalization of European Budgetary

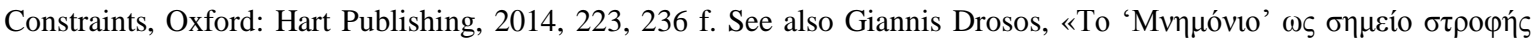

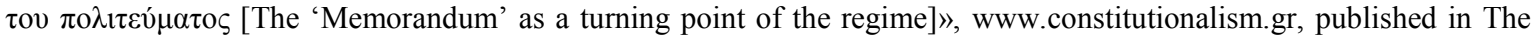
Book's Journal, Vol. 6, April 2011, 42.

${ }^{28}$ Article 93, law 3862/2010, voted on the $5^{\text {th }}$ of July 2010. It is interesting to note that it is the creditors that asked that this obligation be included in the statute, in order to ensure that the loan agreements enjoy a certain degree of political consensus.

${ }^{29}$ See the report on Greece, p. $94 \mathrm{f}$.

30 Source of translation: http://www.hellenicparliament.gr/UserFiles/f3c70a23-7696-49db-9148-f24dce6a27c8/001-156 $\% 20$ aggliko.pdf.

${ }^{31}$ Typically, these acts start with a statement that the Government took into account the 'extraordinary circumstances of an urgent and unforeseeable need to ...' take the measures each time contained in the act. See for example, the acts ratified by the statute $4111 / 2013$, OJ 98 A'/25.01.2013. 
ratified en masse, under the emergency procedure..$^{32}$ The excessive use of "acts of legislative content" has provoked strong reactions in the political world, even by members of the government coalitions. It bears a strong symbolic meaning as well: the extensive use of this instrument by Ioannis Metaxas in the 1930s completely degraded the role of Parliament at the time and finally led to the dictatorship of 1936.

The public television and radio was shut down after the issuing of such an act expanding the legislative authorization granted the administration on the matter. ${ }^{33}$ The closing of the public media was presented by the Government as satisfying a requirement set by the troika for reducing the number of public employees. This was denied by the creditors. Whatever its substantive source and the reasons for the emergency, the act of legislative content was never ratified by Parliament and is therefore no longer valid. However, it has succeeded in producing in full its de facto consequences.

Is it then "the normative power of the facts" 34 that regulates political life in Greece? In any case, the Constitution proves ineffective when faced with economic rules and European economic integration. The emergency and the need for technocratic expertise leave no place for parliamentary discussion or scrutiny.

\section{Italy}

As in other Member States, one can well imagine the struggles Italy has faced to comply with Eurocrisis law measures. There has not been formal recognition of a 'state of emergency' at the local level, yet the idea of exceptionality and its derogatory nature becomes apparent in a distorted use of legal sources. This has been evidenced in the much discussed and still on-going process of reforming the constitutional system of decentralisation of the Republic.

As is well-known, the historical heritage of profound fragmentation of the pre-unified Italian peninsula and the influence of the French-Napoleonic model of decentralized local administration shaped the strong role traditionally attached to Italian municipalities (Comuni) and to the Provinces as superordinate territorial authorities. ${ }^{35}$ The latter already existed in some pre-unitary states, and were already adopted in their current form from the French system by the Kingdom of Sardinia in $1859 .{ }^{36}$ They were subsequently applied in the Lombardo-Venetian and in the other southern and central territories during the unification process by the interim dictators. ${ }^{37}$ The coexistence of Comuni and Province was generally restated by the Legge sull'amministrazione comunale e provinciale of 20th March $1865^{38}$. The Republican Constitution of 1948 would confirm their existence while adding new entities with legislative and administrative powers, the Regions, modelled on the old compartments

\footnotetext{
${ }^{32}$ Cf. for example the statute $4111 / 2013$, cited above. This statute ratified, under the emergency procedure, six decree-laws containing various complex and totally irrelevant provisions. Among them, there were certain austerity measures, as well as an amendment of the Second Loan Agreement.

${ }^{33}$ Cf. Act OJ A' 139/11.6.2013, available at http://www.dsanet.gr/Epikairothta/Nomothesia/ pnp11_6.htm. This act was the legal basis of the Decision 02/11.6.2013, "Suppression of the public enterprise Greek Radio - Television, A.E. (ERTA.E.)", OJ B' 1414/11.6.2013, issued the next day.

${ }^{34}$ Lina Papadopoulou, “Can Constitutional Rules, Even if ‘Golden', Tame Greek Public Debt?”, cited above, 239.

35 See the comparative analysis by L. Vandelli, Poteri Locali: le origini nella Francia rivoluzionaria, le prospettive nell'Europa delle regioni, Il Mulino, Bologna, 1990, and recently M. Mazza, Federalismo, regionalismo e decentramento nella prospettiva della comparazione tra i sistemi di amministrazione (o governo) locale, in 4 Istituzioni del federalismo 2012, pp. 829-856.

${ }^{36}$ With the so called Decreto Rattazzi, legge 23 ottobre 1859 n. 3702 del Regno di Sardegna.

${ }^{37}$ See for details A. Sandulli, G. Vesperini, L'organizzazione dello Stato unitario, in 1 Rivista trimestrale di diritto pubblico, 2011,47 , in particular at p. 58.

${ }^{38}$ See for a comprehensive study F. Fabrizzi, La Provincia. Analisi dell'ente locale più discusso, Jovene, Napoli, 2012.
} 
used for statistical purposes in the Kingdom. ${ }^{39}$ The introduction of the Regions was intended to replace the Provinces ${ }^{40}$ but an inertial solution prevailed both in the Constitution ${ }^{41}$ and in later rounds of constitutional reform, ${ }^{42}$ leaving the Provinces together with municipalities and Regions. This was accompanied by a general, repeated debate at the political level on the futility of the middle layer of government. $^{43}$

The decades of inertia were broken by the supranational (co)action. The letter addressed by the thenPresident of the ECB Jean-Claude Trichet and his designated successor, then a member of the Executive Board of the ECB, Mario Draghi, to the President of the Italian Council of Ministers on $5^{\text {th }}$ August 2011 - programme of the application of the Securities Markets Programme (SMP) to Italy in 2011 and 2012 with the purchase of 102,8 billions of euro of Italian bonds ${ }^{44}$ - explicitly emphasized the "need for a strong commitment to abolish or merge some intermediate levels of administration (such as provinces)' ${ }^{45}$ As is well known, in late 2011 a "technical" Government of so called "national commitment" led by Prof. Mario Monti, with clear pro-European traits and a coherent mandate to solve the critical Italian situation, ${ }^{46}$ replaced the resigned Berlusconi IV government. In one of its first interventions, the Decree-law n. 201/2011 containing various '(U)rgent measures for growth, fairness and consolidation of public accounts', ${ }^{47}$ the new Government tried to comply with these (and other) suggestions of the ECB's letter: it dictated inter alia the transformation of Provinces into institutions with mere functions of direction and coordination of the municipalities, governed by a council and a

${ }^{39}$ For several reasons, both theoretical and contingent: see for comprehensive accounts, ex multis, the pioneering studies of A. Amorth, Il problema della struttura dello Stato in Italia. Federalismo, regionalismo, autonomismo, Marzoranti, ComoMilano, 1945, and G. Ambrosini, L'ordinamento regionale. La riforma regionale nella Costituzione italiana, Zanichelli, Bologna, 1957, and the recent summary by A. D'Atena, Diritto regionale, Giappichelli, Torino, 2013, pp. 9 et seq.. In the literature in English, see now S. Mangiameli (ed.), Italian Regionalism: Between Unitary Traditions and Federal Processes. Investigating Italy's Form of State, Springer, 2014.

${ }^{40}$ Both the discussions in the context of the Ministero per la Costituente, established with decreto luogotenenziale 31 luglio 1945, n. 435, and in the Commissione dei settantacinque within the Constituent Assembly were in this sense: see F. Fabrizzi, La Provincia: storia istituzionale dell'ente locale più discusso. Dalla riforma Crispi all'Assemblea Costituente, in Federalismi.it. Rivista di diritto pubblico italiano, comunitario e comparato, n. 12/2008, available at the webpage http://goo.gl/ipCTT8.

${ }^{41}$ See for instance the rejected proposal of the Partito Repubblicano Italiano in 1977 "Soppressione dell'ente autonomo territoriale provincia: modifica degli articoli 114, 118, 119, 128, 132, 133 e della VIII disposizione di attuazione della Costituzione; abrogazione dell'articolo 129 della Costituzione", based explicitly on «a chain of negative findings on the institutional and administrative role of the province».

${ }^{42}$ For instance, all the bicameral committees convened to draft organic reforms of the Italian Constitution (the Commissione Bozzi of 1983, the Commissione De Mita/Iotti of 1992, the Commissione D'Alema of 1997) critically discussed the actual role and the very existence of the Provinces, but with no results: see F. Fabrizzi, La Provincia: storia istituzionale dell'ente locale più discusso. Dall'Assemblea costituente ad oggi, in Federalismi.it. Rivista di diritto pubblico italiano, comunitario e comparato, n. 23/2008, available at the webpage http://goo.gl/HQWsQ2.

${ }^{43}$ Again at the end of June 2010, a proposal to abolish the Provinces with less than 220.000 inhabitants made its way in a draft of the Decree-Law n. 78/2010, but then disappeared from the official text; in July 2011, a new constitutional bill for their suppression (XVI Legislatura, AC n. 1990-1836-1989-2264-2579-A/R) was rejected.

${ }^{44}$ The largest quota among all the Eurozone members: see the details provided by the European Central Bank at its webpage http://www.ecb.europa.eu/press/pr/date/2013/html/pr130221_1.en.html.

${ }^{45}$ See the full text, as revealed at the time by the Italian main newspaper, the Corriere della Sera, at the webpage http://www.corriere.it/economia/11_settembre_29/trichet_draghi_italiano_405e2be2-ea59-11e0-ae064da866778017.shtml.

${ }^{46}$ In itself seen by some observes as evidence of a state of exception, given the particularly active role of the President of the Republic in such appointment: see for an early reflection on the point A. Ruggeri, Art. 94 della Costituzione vivente: 'Il Governo deve avere la fiducia dei mercati' (nota minima a commento della nascita del Governo Monti), in Federalismi.it. Rivista di diritto pubblico italiano, comunitario e comparato, n. 23/2011, available at the webpage http://goo.gl/10spCn.

${ }^{47}$ Decreto-legge 6 dicembre 2011, n. 201 - Disposizioni urgenti per la crescita, l'equita' e il consolidamento dei conti pubblici. (11G0247) (GU n.284 del 6-12-2011 - Suppl. Ordinario n. 251 ). 
president elected by the municipalities themselves, and devoid of a collegiate executive and ultimately of autonomy.

The most relevant aspect is in the choice of the formal measure used, at least originally, to implement the reform. In the Italian legal system, Decrees-laws are legislative acts of a temporary nature having the force of law, adopted directly by the Government in 'extraordinary cases of necessity and urgency' pursuant to Art. 77 of the Constitution of the Italian Republic. A subsequent vote by Parliament, that must take place within 60 days of publication, converts them into a formal Law. Nonetheless, the practical use of Decree-Laws has been trivialized by their extensive use by the Government, to circumvent the ordinary legislative procedure. For these cases, the Italian Corte costituzionale has often underlined the dimension of political discretion in their use, ${ }^{48}$ and has rarely struck down legislative measures for reasons relating to their selection, misuse of the procedure and a failure to fulfil the relevant criteria. ${ }^{49}$

The Decree-law no. 201/2011 had a different fate. It was challenged together with the Decree-law no. 95/2012 (which set the basis for the reorganization of the Provinces' territorial constituencies) by a series of Regions before the Corte costituzionale. The two Decrees were actually converted into Laws by the legislature. However, in view of the appellants these norms could be considered as running counter to various aspects of the concept of autonomy of territorial entities, ranging from the respect of their core competences to the principle of loyal cooperation in the context of a radical reform.

The Court's intervention (judgment n. 220/2013) explicitly left untouched the 'merits of the choices made by the legislature'. It pointed solely to the abnormality of the source of law employed. ${ }^{50}$ The urgency invoked by the Government for the use of a Decree-law was held up against the explicit aim of an organic constitutional reform of the territorial organization of the Republic. This reform could be linked to the short-term necessity of immediate revenue savings but it necessarily required a long-term process of implementation, requiring the 'suspension of effectiveness, referrals and progressive systematizations' ${ }^{51}$ This was difficult to reconcile with the immediacy of effects typical of the Decreelaw according to the constitutional design. Moreover, the use of a Decree-law to modify the Provinces' territorial constituencies was also found to constitute a radical breach of the constitutional requirement (a 'logical and legal incompatibility') contained in Article 133 of an initiative of the relevant Comuni (municipalities). The misuse of a specific source was therefore sanctioned with a declaration of unconstitutionality. In doing so, the Corte highlighted the split between the transient nature of the Decree-laws and the importance of constitutional reform and, implicitly, the difference between the preordained urgency inherent in the employment of Decree-laws and the extraordinary situation of emergency that the reform tried to combat. ${ }^{52}$

In the meantime, another governmental Decree-Law, n. 188/2012, ${ }^{53}$ was issued in order to identify the new territorial constituencies of the Provinces. However, this time around the Decree-law was never converted into law by the Parliament, and its effects therefore expired. A legislative bill to regulate the

\footnotetext{
${ }^{48}$ See for instance Corte Costituzionale 23 maggio 2007, n. 171, at par. 4 of the Considerato in diritto.

${ }^{49}$ This created a paradoxical convergence with the practice of the Fascist period, when a formal law, the Legge 31 gennaio 1926, n. 100, explicitly provided for the exclusion of judicial review on the criteria of necessity and urgency, as "political questions": see M. Benvenuti, Alle origini dei decreti-legge. Saggio sulla decretazione governativa di urgenza e sulla sua genealogia nell'ordinamento giuridico dell'Italia prefascista, in Scritti in onore di Claudio Rossano, Jovene, Napoli, 2013, I, pp. 21-79.

${ }^{50}$ See Corte Costituzionale 19 luglio 2013, n. 220, at par. 12.1 of the Considerato in diritto.

${ }^{51}$ Ibid.

${ }^{52}$ See for an analysis of the two dimensions R. Bin, Il nodo delle province, and G. Di Cosimo, Come non si deve usare il decreto legge, in 5-6 Le Regioni, 2013, at pp. 899-912 and pp. 1163-1167 respectively.

${ }^{53}$ Decreto-legge 5 novembre 2012, n. 188. Disposizioni urgenti in materia di Province e Citta' metropolitane (12G0210) (GU n.259 del 6-11-2012).
} 
"second-order" elections of the Provinces' organs was also presented by the Government in May $2012^{54}$ but again, the parliamentary approval never came. Instead, the annulment of the relevant parts of the Decree-laws n. 201/2011 and n. 95/2012 by the Corte costituzionale led to a further stratification and complication of measures on the same matters. For instance, during the same week as the hearing of the Corte (whose results were anticipated by a press release) the Council of Ministers deliberated the approval of a radical constitutional bill intended to eliminate the Provinces from the Italian constitutional architecture. ${ }^{55}$ Moreover, new interim measures were considered necessary to consolidate, after the Corte's intervention, the effects of the other, non-annulled parts of the Decreelaws nos. 201/2011 and 95/2012. Thus, the Decree-law n. 93/2013 (devoted to 'Urgent provisions for civil security and to combat gender-based violence, as well as on the subject of civil protection and commissioned administration of the Provinces': ${ }^{56}$ a case study of an "inhomogeneous" Decree) confirmed the dissolution of the political organs of the remaining Provinces, the nomination of the Government's Commissioners and the efficacy of the latter's acts. The Law no. 147/2013 provided the same effects for those Provinces whose organs had naturally expired or been terminated early between $1^{\text {st }}$ January and $30^{\text {th }}$ June 2014.

A new Law n. 56/2014 was then recently approved, establishing the new Città metropolitane already envisioned in the constitutional reform of 2001 and regulating the new Unioni di Comuni ("unions of municipalities"). There is a clear overlap in the competences between these new layers of territorial government and the Provinces; in fact, the Law n. 56/2014 also aims at establishing the current legal framework of the Provinces, by transforming them into second-level authorities, with no directly elected organs but composed of representatives of the relevant municipalities.

There is a clear, and commendable, tendency towards optimization and reduction of expenditure, for instance with regard of the eradication of a whole layer of local representatives (Article 1, paragraph 84 of the Law explicitly provides for the non-remunerated nature of the political appointments at the Provinces' level).

However, again problematic issues of form arise.

There remain doubts regarding the constitutionality on the merits of the reform as possibly undermining the autonomy of local authorities, which have yet to be dealt with by the Corte Costituzionale n. 220/2013. However, the first tangible concern is in the structure of the Law n. 56/2014, composed of a single article with 151 (sic) internal paragraphs and an attachment. In this sense, emergency is visible here in the use of an already infamous Italian drafting technique, aimed at a reducing the time needed to gain the approval of Parliament, but certainly detrimental for the legislative quality. ${ }^{57}$

\footnotetext{
${ }^{54}$ Disegno di legge "Modalità di elezione del Consiglio provinciale e del Presidente della Provincia, a norma dell'articolo 23, commi 16 e 17, del decreto-legge 6 dicembre 2011, n. 201, convertito, con modificazioni, dalla legge 22 dicembre 2011, n. 214" (5210).

${ }^{55}$ Disegno di legge costituzionale: "Abolizione delle province" (1543), presented on the 20th August 2013 at the Camera dei Deputati: see the text at the webpage of the lower house of the Parliament http://www.camera.it/ _dati/leg17/lavori/stampati/pdf/17PDL0009060.pdf.

${ }^{56}$ Decreto-legge 14 agosto 2013, n. 93 Disposizioni urgenti in materia di sicurezza e per il contrasto della violenza di genere, nonche' in tema di protezione civile e di commissariamento delle province (13G00141) (Gazzetta Ufficiale n.191 del 168-2013), convertito con modificazioni dalla L. 15 ottobre 2013, n. 119 (in G.U. 15/10/2013, n. 242).

${ }^{57}$ And therefore for the prerogatives of the Parliament and for the certainty of the law: see on these points, ex multis, A. Pisaneschi, Fondamento costituzionale del potere di emendamento, limiti di coerenza e questione di fiducia, in 2 Diritto e società, 1988, pp. 203-258; M. Ainis, La legge oscura. Come e perchè non funziona, Laterza, Roma-Bari, 1997, p. 4; G.U. Rescigno, L'atto normativo, Zanichelli, Bologna, 1998, pp. 139 et seq.; N. Lupo, Emendamenti, maxi-emendamenti e questione di fiducia nelle legislature del maggioritario, in E. Gianfrancesco, N. Lupo, (eds.) Le regole del diritto parlamentare nella dialettica tra maggioranza e opposizione, LUISS University Press, Roma, 2007, pp. 41 et seq.; G. Piccirilli, L'emendamento nel processo di decisione parlamentare, CEDAM, Padova, 2009, especially pp. 223 et seq..
} 
Secondly, the technique used in passing the Law n. 56/2014 is somewhat perplexing. It makes continuous reference to '(P)ending of the reform of Title V of Part II of the Constitution and of its implementing rules (...)' (Article 1, paragraphs 5 and 51), and therefore also to the aforementioned constitutional bill of radical suppression of the Provinces. Not only is the approval of such reform is uncertain on both a legal and political level at the current stage, but it has been also argued that the entire Law, as an organic reform with no contextually clear fundamental choices about the overall structure of local government, is disproportionate as a means to make a new round of elections of Provinces' representatives impossible. ${ }^{58}$

To conclude, a reform of clear constitutional significance for the Italian Republic has been undertaken with clear distortions of the relevant sources of law.

A whole range of pathologies in the employment of sources is detectable, all intervening, all of a sudden, in matters historically difficult to amend: ${ }^{59}$ patent misuse of Decree-laws, unconverted or of a compendious quality, withdrawn governmental bills, repeated interim measures to block elections, unconstitutional drafting of organic reforms, with dubious formal renvois to uncertain constitutional amendments still to be approved.

\section{Spain}

With a reshuffle of labour rights akin to Portugal and a regime of governmental re-centralisation similar to that of Italy, Spain has also witnessed profound legal changes in the aftermath of the Eurocrisis. The sense of economic emergency has been evident not only in the substantive content of the reforms but also in the vehicles used for their approval: the crisis has been tackled with executivedominated legislation that effectively bypasses parliamentary debate or strongly limits it. Judicial review of these measures has been lenient, the language of emergency having penetrated most recent judicial decisions of the Constitutional Court.

The first amendment to the Spanish labour regime took place in 2010 during the final period of the Zapatero's socialist government. As unemployment reached worrying levels and the Spanish risk premium escalated, a Royal Decree-law ${ }^{60}$ made significant reductions in the salaries of civil servants, among other deficit-correcting measures. The cuts, which openly breached the collective agreements in force at the time, were followed by further amendments of the general labour law regime. Royal Decree-law 7/201 ${ }^{61}$ modified the regime of collective bargaining so as to make collective negotiation more flexible. For example, the application of agreements reached within individual enterprises was prioritised over those reached with the relevant economic sector. Additionally, provinces ${ }^{62}$ could no longer shape the regime of collective bargaining. With the advent of Rajoy's conservative government, Royal Decree-law 3/2012 $2^{63}$ reduced the severance payments of indefinite job contracts and created a one-year contract with no severance payment. The same Decree-law specifies economic circumstances under which the employer can reduce the wages or the working time of employees.

\footnotetext{
${ }^{58}$ See in this regard F. Giglioni, La riforma del governo di area vasta tra eterogenesi dei fini e aspettative autonomistiche, in Federalismi.it. Rivista di diritto pubblico italiano, comunitario e comparato, n. 1/2014, available at the webpage http://goo.gl/OaM02G.

${ }^{59}$ See also F. Fabrizzi, Il caos normativo in materia di province, in Federalismi.it. Rivista di diritto pubblico italiano, comunitario e comparato, n. 1/2014, available at the webpage http://goo.gl/UiE7vi.

${ }^{60}$ Royal Decree-law 8/2010 of 20 May adopting extraordinary measures for the reduction of the public deficit. Boletín Oficial del Estado No. 126, 24 May 2010.

${ }^{61}$ Royal Decree-law 7/2011 of 10 June on urgent measures for the reform of collective bargaining. Boletín Oficial del Estado No. 139, 11 June 2011.

${ }^{62}$ Hence at the moment only regions and state legislation can regulate the conditions surrounding collective bargaining.

${ }^{63}$ Royal Decree-law 3/2012 of 10 February on urgent measures for the reform of the labour market. Boletín Oficial del Estado No. 36, 11 February 2012.
} 
Lastly, Royal Decree-law 20/2012 $2^{64}$ included among others a provision allowing for the suspension of collective agreements of public employees when the Government considers a severe economic situation to be taking place.

These significant labour law reforms have figured prominently in public and academic discussions, having being termed as a true 'deconstitutionalisation' of the Spanish labour law regime. ${ }^{65}$ An alleged extreme necessity for reform becomes apparent in the preambles of all these Decree-laws. These include acknowledgements of the unprecedented gravity of the current crisis ${ }^{66}$ and the need for reforms for the viability of public finances and economic growth. ${ }^{67}$ Remarkably, the feeling of emergency has also led to a distorted use of legislative sources in order to tackle the crisis: the Royal Decree-law, an instrument enacted exclusively by the Executive, has replaced the use of ordinary laws as the main instrument of legislation.

The Royal Decree-law is a norm with the status of a law that can be passed by the Government in case of 'extreme and urgent necessity'. ${ }^{68}$ The Decree-law becomes binding from its date of publication (which often takes place few days after its approval). However, for its content to become 'permanent' it needs the approval of the Congress of Deputies (the lower chamber of the Spanish Parliament) within thirty days from the date of its promulgation. This approval consists of a vote over the Decreelaw as a whole, after which the Decree-law becomes an ordinary law. The Decree-law therefore becomes a means of passing ordinary laws while avoiding parliamentary debates on the substantive content of the law in question.

Whereas in 2005 the matters regulated by the Decree-law consisted mainly of natural disasters, weather-related setbacks and terrorist events, from 2009 onwards most Decree-laws focus on economic matters. The number of Decree-laws has increased progressively since 2008 and had by 2012 (when the lion's share of anti-crisis measures were approved) completely dominated legislative activity. It seems that the Government has opted for regulating the crisis through an instrument that bypasses any sort of parliamentary debate even though its qualified majority at the Parliament would have guaranteed the approval of ordinary laws. This phenomenon has been referred to as the "use and abuse of the Decree-law' ${ }^{69}$ The most recent illustration of the abusive recourse to the Decree-law in 2014 has enabled the Government to reform 25 ordinary laws with a single mechanism. ${ }^{70}$ Among the issues affected are not only labour-related provisions such as measures to promote youth employment, but other topics whose need for urgent legislation is doubtful, such as the management of the Civil Register and the regulation of unmanned drones.

The assessment of what constitutions an 'extreme and urgent necessity' is the most problematic issue of the Royal Decree-law. In this regard, the Spanish Constitutional Court has stated that whereas the existence of an urgent necessity is a political judgement of a discretionary nature, ${ }^{71}$ the Government cannot use the Decree-law for tackling issues that are structural rather than unexpected. ${ }^{72}$ In addition,

\footnotetext{
${ }^{64}$ Royal Decree-law 20/2012 of 13 July on measures for guaranteeing budgetary stability and the promotion of competitiveness. Boletín Oficial del Estado No. 168, 14 July 2012.

${ }^{65}$ A Baylos, 'La deconstitucionalización del trabajo en la reforma laboral del 2012', Revista de Derecho Social 61, $2013, \mathrm{p}$. 29.

${ }^{66}$ Preamble of the Royal Decree-law 3/2012 (above no. 4).

${ }^{67}$ Preamble of the Royal Decree-law 20/2012 (above no. 5).

${ }^{68}$ Article 86 of the Spanish Constitution. Boletín Oficial del Estado No. 311, 29 December 1978.

${ }^{69}$ A Díaz de Mera Rodríguez, 'Gobierno de Crisis. Uso y abuso del Decreto-ley', in Revista Parlamentaria de la Asamblea de Madrid No. 24, June 2011, pp. 137 - 179.

${ }^{70}$ Royal Decree-law 8/2014 of 4 July, passing urgent measures for growth, competitiveness and efficiency. Boletín Oficial del Estado No. 163, 5 July 2014.

${ }^{71}$ Sentencia del Tribunal Constitucional 29/1982. Boletín Oficial del Estado No. 153, 28 June 1982.

${ }^{72}$ Sentencia del Tribunal Constitucional 68/2007. Boletín Oficial del Estado No. 100, 26 April 2007.
} 
the Spanish Constitution poses limits to the fields that can be regulated by a Royal Decree-law. The basic institutions of the State; the rights, duties and freedoms of the citizens, the regime of the Regions and the electoral regime can only be altered by an Organic Law. Be that as it may, it seems that fundamental rights have indeed been affected by the Government's reforms of the labour law regime and the right to collective bargaining. ${ }^{73}$

Gómez Lugo has pointed out that the use of Decree-laws could have been substituted by the approval of ordinary laws through an abbreviated procedure. ${ }^{74}$ This would have shortened the timing of the parliamentary proceedings while allowing for wider debates on the content of the legislation. However, the use of abbreviated procedures during the Euro-crisis has not been exempted from criticism given that parliamentary debates have been restricted relative to the magnitude of the issues. In 2011, an amendment of Article 135 of the Spanish Constitution was carried out so as to give constitutional status to the principle of budgetary stability. This amendment was initiated a few days after Rodríguez Zapatero received a letter from the European Central Bank prompting him to 'take audacious measures that guaranteed the sustainability of public finances' ${ }^{75}$ Article 135 was among the sections of the Constitution that could be modified through a simplified procedure (with a three-fifth majority at both the Congress and the Senate and without referendum). The Government further shortened the parliamentary formalities by processing the initiative of amendment through the 'single reading procedure' and passing the amendment itself through the 'urgent procedure'. ${ }^{76}$ The two largest parties (the governing Socialist Party and the opposing Popular Party) had previously agreed on the content of the constitutional amendment. In contrast, the other parliamentary groups complained that they had not had time to react to an amendment they hardly expected. ${ }^{77}$ Only thirty-two days passed from the proposal of the amendment to its approval, hence the title of 'express reform' being applied to the amendment. ${ }^{78}$

Whereas the main intention of the new Article 135 was to ensure that Spain would be sufficiently solvent to cover its external commitments, the amendment has also reinforced the move towards recentralisation of regional and local finances that has been taking place since $2012^{79}$. Directive 2011/85 ${ }^{80}$ (part of the Six-Pack) prompted Member States to exercise tighter control over the finances of their different subsectors of government. This mandate was particularly sensitive in the Spanish context, where regions and municipalities enjoy constitutionally reserved competences (the regional 'Statutes of Autonomy' enjoying constitutional status). Rajoy's conservative government brought into effect most of this re-centralising trend contained in the Organic Law 2/2012 on Budgetary Stability ${ }^{81}$,

\footnotetext{
${ }^{73}$ See M L Rodríguez 'Labour Rights in Crisis in the Eurozone: The Spanish Case' in C Kilpatrick and B de Witte (eds.) Social Rights in Times of Crisis in the Eurozone: The Role of Fundamental Rights' Challenges, pp. $104-113$.

${ }^{74}$ The abbreviated procedures foreseen by the Spanish legislation are the 'single reading procedure' (which omits the opinions and reports that would normally be issued by the Parliamentary Committees) and the 'urgent procedure' (which substantially reduces the time periods for proposing amendments to the bill). See Y Gómez Lugo, 'Decreto Ley versus Ley parlamentaria: Notas sobre el uso de la legislación de urgencia' in Eunomia, No. 4, Mar - Aug 2013, pp. 102 - 117.

${ }^{75}$ Letter available at http://ep00.epimg.net/descargables/2013/11/27/2b10649fe77a0775a23fb7eb465ab974.pdf.

${ }^{76}$ See footnote no. 11 above.

${ }^{77}$ Diario de Sesiones del Congreso de los Diputados No. 270 of 2 September 2011, http://www.congreso.es/public_oficiales/L9/CONG/DS/PL/PL_270.PDF.

${ }^{78}$ El País, 23 August 2011, available at

http://politica.elpais.com/politica/2011/08/23/actualidad/1314128715_080054.html.

${ }^{79}$ See E Alberí Rovira, "El Impacto de la Crisis en el Estado Autonómico Español”, Revista Española de Derecho Constitucional No. 98, May- August 2013 at p. 69.

${ }^{80}$ Council Directive 2011/85/EU of 8 November 2011 on requirements for budgetary frameworks of the Member States, Official Journal L 306 of 23 November 2011.

${ }^{81}$ Ley Orgánica 2/2012, of 27 April, on Budgetary Stability and Financial Sustainability. Boletín Oficial del Estado No. 103 , 30 April 2012.
} 
which included among other measures strict sanctions if the regions breach their budgetary commitments (even the suspension of their taxation competences) and financial assistance under strict conditionality for those regions who request it. Some authors have pointed out that the Law on Budgetary Stability was in breach of the constitutionally guaranteed division of competences between State and Regions. ${ }^{82}$ However, in recent decisions the Spanish Constitutional Court, when deciding on the constitutionality of the previous Laws on Budgetary Stability, used the new Article 135 in order to dismiss any doubt of unconstitutionality. According to the Court, the requirement of budgetary stability is now placed beyond the powers of both the central government and those of the Regions, and hence a tight control of the regional finances cannot be understood as a usurpation of regional competences but as a constitutional imperative in itself.

The permissiveness of the Spanish Constitutional Court vis-à-vis the reforms of the Laws on Budgetary Stability can be seen as an example of its more general permissive attitude towards the actions of the executive. Indeed, judicial reactions to the emergency legislation have been remarkably lenient. The Court has declared the action of unconstitutionality against the amendment of the Spanish Constitution as inadmissible on the grounds (inter alia) that there were reasons of exceptional nature enabling the Parliament to use the 'urgent procedure' and to reduce the time limits substantially, even if the applicants did not agree politically with such reasons. ${ }^{83}$ The Constitutional Court also declared the Decree-law reforming the Statute of the Personnel of the Public Administration to be constitutional. The Court based its reasoning on the consideration that the Decree-law did not attack the content or the essential elements of the right to collective bargaining given that, within the legal hierarchy, collective agreements are always subject to legislation of legal status. ${ }^{84}$ Finally, the Constitutional Court has also dismissed the actions of unconstitutionality lodged against the labour law reforms of 2012. The Court upheld the right of the Government to introduce the reforms through a Decree-law, using the argument that the clear evidence from the economic crisis and unemployment levels justified the invocation of an extraordinary and urgent necessity. ${ }^{85}$ In a recent decision, the Court has also validated the one-year contract without severance payment by considering it a circumstantial measure linked to a situation of emergency: the soaring levels of unemployment. ${ }^{86}$

In hindsight one can state that the use of emergency legislation in Spain has enabled more speedy reactions at the expenses of political and social dialogue. That said it is not clear to what extent the Euro-crisis law has respected the boundaries set by the Spanish Constitution. The reform of the Spanish labour law regime through Decree-laws has, in all likelihood, infringed the prohibition of altering fundamental rights with this instrument, the new Law on Budgetary Stability has significantly altered the constitutional balance between central government and regional entities, and the 'express' reform of the Spanish Constitution seems to further reinforce this re-centralising move (furthermore the fact that it will only enter into force in 2020 calls into question the need of approval through the urgent procedure). However the permissive decisions of the Constitutional Court have also invoked the language of emergency, avoiding a direct confrontation with the measures taken in order to contain the crisis.

\footnotetext{
${ }^{82}$ For instance M Medina Guerrero, "El estado autonómico en tiempos de disciplina fiscal”, Revista Española de Derecho Constitucional No. 98, May- August 2013; also E Albertí Rovira, (above no. 20).

${ }^{83}$ Auto del Tribunal Constitucional 9/2012. Boletín Oficial del Estado No. 36, 11 February 2012.

${ }^{84}$ Sentencia del Tribunal Constitucional 85/2011; Boletín Oficial del Estado No. 158, 7 June 2011. The Spanish Constitutional Court had previously declared social dialogue to bear a transcending value in a social and democratic rule of law (Sentencia del Tribunal Constitucional 68/2007; Boletín Oficial del Estado No. 100, 26 April 2007).

${ }^{85}$ Auto del Tribunal Constitucional 164/2014 (not officially reported, available at http://www.tribunalconstitucional.es/ es/jurisprudencia/Paginas/Auto.aspx?cod=24054).

${ }^{86}$ Sentencia del Tribunal Constitucional 119/2014; Boletín Oficial del Estado No. 198, 15 August 2014. Note that the Spanish Constitutional Court had previously declared that severance payments in cases of unfair dismissal are part of the essential content of labour law (Sentencia del Tribunal Constitucional 20/1994; Boletín Oficial del Estado No. 52, 2 March 1994).
} 
Even if the Euro-crisis law is accepted as constitutional, it would still pose a normative dilemma. Not only does Euro-crisis legislation touch upon extremely sensitive issues, but it does so in an enduring manner. Most of what has been enacted during the crisis will remain in place in the event of an economic recovery. Under the emergency narrative, topics closely linked to the Spanish 'social contract' have been regulated outside parliamentary debate and avoided social contestation. This challenges the classic notion of 'emergency' in which permanent institutional reforms were forbidden ${ }^{87}$, and calls for a reflection on the limits that the executive should respect even when allegedly responding to events that threaten the viability of the system.

\section{Ireland}

Article 28.3.3 ${ }^{\circ}$ Bunreacht na hÉireann (the Constitution of Ireland) provides that 'nothing in this Constitution... shall be invoked to invalidate any law enacted by the Oireachtas which is expressed to be for the purpose of securing the public safety and the preservation of the State in time of war or armed rebellion,. ${ }^{88}$ While the economic and financial crisis that engulfed the state in 2008 and subsequent years has frequently been described as a period of general crisis, an attempt to draw an analogy to Article $28.3 .3^{\circ}$ by invoking a legal emergency arising from the economic crisis has generally not been a feature of the Irish implementation of Eurocrisis law. Unlike other Member States implementing structural reforms as a result of EU/IMF programmes, Ireland has not made use of exceptional legislative procedures or other forms of constitutional derogations. Nonetheless, an awareness on the part of the courts to the general political and above all financial context of some of the measures adopted to combat the economic crisis has emerged in certain discrete areas, particularly in relation to measures adopted in the immediate aftermath of the financial crisis to deal with the state's deteriorating financial position and its insolvent banking system.

The principal effect of this awareness has been to extend the discretion afforded the Government. At the same time this has been done within the scope of existing legal concepts and tests and the need to remain within the bounds of the Constitution, even when dealing with a national economic emergency, has been stressed by the Supreme Court. Ireland thus appears as a relative exception amongst the programme Member States of the Union. A possible explanation for this anomaly may lie in certain features of the Irish constitution and legal-political culture, in particular an especially strong executive and a relative absence of an economic and social rights culture in Ireland.

The area where the state's economic circumstances have played the greatest role in the reasoning of the courts is that of public sector employment and in particular efforts to reduce public sector pay and pensions. The Financial Emergency Provisions in the Public Interest Act 2009 (FEMPI Act 2009), ${ }^{89}$ granting the Government the power to impose a levy on public servants to fund their pensions and to reduce payments to service providers has been challenged, unsuccessfully, before the courts on the grounds of property rights. In all cases the High Court has noted the special circumstances and purposes of the FEMPI Act 2009 in contributing to the stabilisation of the State's finances and in ensuring that the public sector makes a 'fair contribution' to such a stabilisation. In Haire ${ }^{90}$ and $U_{N I T E}{ }^{91}$ the High Court found that the economic context in which the FEMPI Act 2009 was adopted and its stated public interest purposes supported the conclusion that any purported attack on property

\footnotetext{
${ }^{87}$ See J Ferejohn and P Pasquino, 'The law of the exception: A typology of emergency powers', Int J Constitutional Law 2(2), 2004, p. 211.

${ }^{88}$ Bunreacht na hÉireann, art 28.3.3․

${ }^{89}$ Financial Emergency Provisions in the Public Interest Act 2009.

${ }^{90} J$ \& J Haire \& Company Ltd \& Ors v Minister for Health and Children \& Ors [2009] IEHC 562.

${ }^{91}$ UNITE \& anor v Minister for Finance [2010] IEHC 354.
} 
rights would not be 'unjust' within the meaning of Article $40.3 .2^{\circ}$ of the Constitution. ${ }^{92}$ In Garda Representative Association, the High Court, while in general discussing the provisions of the FEMPI Act 2009 itself rather than the constitutional context, found that when deciding whether to exclude a particular group (in this case the police) from the pension levy, the Minister for Finance had a significant degree of discretion due to the fact that the FEMPI Act 2009 was a question of political choice and was 'both policy-based and fiscal'. ${ }^{93}$ Finally, most strikingly, in McKenzie, the High Court found that the Minister for Defence was entitled to bypass a Conciliation and Arbitration scheme (the $\mathrm{C} \& \mathrm{~A}$ Scheme) when imposing a general government-wide reductions in allowances for travel. ${ }^{94} \mathrm{In}$ finding in favour of the Minister, the Court found that in adopting measures in response to the 'most serious economic crisis in [the state's] history that has been deepening by the week' the Government was acting 'in the urgent national interest', allowing it to bypass the $\mathrm{C} \& \mathrm{~A}$ Scheme under article 3 of that scheme.

Secondly, the High Court has also highlighted the economic context in the context of the issuance of promissory notes to recapitalise the banking sector. In Collins ${ }^{95}$ the High Court found that once the Oireachtas (Parliament) has authorised the government to make payments for a specific purpose, here in extending financial aid to credit institutions, there is no limit on the amount the government may spend and there is no corresponding need to return to parliament to obtain further authorisation. It should be noted that the Court mentions the economic crisis as a mere context for the discussion and the judgment is a general discussion of the constitutional framework of the budget. However, while the Court expressly excludes the economic context as a relevant consideration in its legal analysis, an emphasis is placed on a need to secure freedom of action for the government in its executive role, with the Court noting that 'as recent experience has all too painfully demonstrated, the welfare of the entire citizenry is hugely dependent on the capacity of the State to be able to raise money without hindrance on international markets. ${ }^{, 96}$

Finally, in the case of Dellway the Supreme Court upheld an individual's constitutional rights to fair procedures in the context of acquisition of loan books by a 'bad bank', designed to remove toxic assets from the Irish banking system after the property market collapse. In doing so it explicitly rejected the contention that the national economic emergency might justify an infringement on constitutional rights. In Dellway an individual challenged the decision of the National Asset Management Agency (NAMA) under the NAMA Act 2009 to acquire his loans from his bank without any hearing. ${ }^{97}$ While a relatively minor part of the decision, a number of judgments indicated a hostility to an attempt by the Government to raise the possibility of an economic state of emergency analogous to the state or war or rebellion found in Article 28.3.3 ${ }^{\circ}$ Bunreacht na hÉireann with Hardiman J noting that '[o]ur Constitution makes specific provision for "war or armed rebellion". It is not for the courts to extend those provisions to a situation which is not one or war or armed rebellion. That would require a decision of the people in a referendum, if they thought it necessary or prudent to confer such unreviewable powers on the State. The cry of "emergency" is an intoxicating one, producing an

\footnotetext{
${ }^{92}$ It should be noted that in Haire (n 90) the Court found that in any event the alleged property right did not in fact exist and it was on this basis the decision was decided.

${ }^{93}$ Garda Representative Association v Minister for Finance [2010] IEHC 78 para 23.This analysis would seem to flow both from the nature of the act as one regulating public sector pay but more importantly from its purpose and general place in the response of the Government to the economic crisis and the policy decision to ensure that the public sector make a proper contribution to its resolution.

${ }^{94}$ McKenzie \& Anor v Minister for Finance \& Ors [2010] IEHC 461.

${ }^{95}$ Collins v Minister for Finance and others [2013] IEHC 530.

96 ibid para 124.

${ }^{97}$ Dellway Investments Ltd et al v National Asset Management Agency et al [2001] 4 IR 1 High Court, Supreme Court.
} 
exhilarating freedom from the need to consider the rights of others and productive of a desire to repeat it again and again. ${ }^{, 98}$

In both the case of the FEMPI Act litigation and the Collins judgment the economic crisis has been invoked directly or served as the context for a facilitation of governmental discretion. In Garda Representative Association the description of the FEMPI Act 2009 as a reaction to the economic crisis and its stated goal to 'share the burden' ensured that the decisions of the Minister were of a political and policy-based nature, thereby ensuring a minimal level of judicial scrutiny. ${ }^{99}$ Similarly in Haire ${ }^{100}$ and $U_{N I T E^{101}}$ the economic crisis served as the context in which any attack on property rights were to be considered proportionate and therefore not unjust within the meaning of the constitution. In McKenzie, explicit reliance is made on Article 3 of the Conciliation and Arbitration Scheme that preserves the Government's liberty of action in the exercise of their constitutional authority. ${ }^{102}$ Finally, in Collins, ${ }^{103}$ the freedom of the Government to act in the national interest was a key consideration in finding that it did not have to return to Parliament in order to secure further authorisation to issue billions of euro in promissory notes.

Nonetheless, in all cases considerations relating to the financial crisis and any 'economic emergency' have been located and accommodated within an existing legal framework, be it the test for an 'unjust' attack on property rights in the cases of Haire ${ }^{104}$ and UNITE ${ }^{105}$ or the constitutional framework for the budget in Collins. ${ }^{106}$ Even McKenzie, perhaps the clearest assertion of a national economic emergency, is fitted within article 3 of the Conciliation and Arbitration Scheme, allowing the scheme to be bypassed if its application would hinder the government in the discharge of its responsibilities in the public interest. ${ }^{107}$ While, particularly in the case of the FEMPI Act litigation, the economic circumstances of the state have had an influence on the legal analysis, in no case has an explicit standalone doctrine of a national economic emergency been developed or applied to justify governmental action that would otherwise be illegal. Indeed, in Dellway, the Supreme Court endorsed this approach of allowing economic circumstances to play a role in legal analysis, such as in a proportionality analysis, while arguing strongly that this is done within the existing legal framework and the Constitution itself. ${ }^{108}$

As is evident from the case studies included in this report a state of legal emergency has tended to arise in two specific contexts; firstly to allow governments to bypass ordinary legislative procedures and pass forms of decree or emergency laws; secondly as a justification for limiting fundamental social rights. On the one hand Ireland has not made use of exceptional or emergency law making procedures to bypass the usual legislative process. On the other hand, while the economic context has been a relevant consideration in certain cases dealing with individual rights, it has not lead to the creation of an explicit application of an emergency powers doctrine overriding individual rights. Rather this has been accommodated within the existing legal concepts available in the Irish legal

\footnotetext{
98 ibid 289.

${ }^{99}$ Garda Representative Association v Minister for Finance (n 93).

${ }^{100}$ Haire (n 90).

${ }^{101}$ UNITE (n 91).

${ }^{102}$ McKenzie (n 8) para 5.3.

${ }^{103}$ Collins (n 95).

${ }^{104}$ Haire (n 90).

${ }^{105}$ UNITE (n 91).

${ }^{106}$ Collins (n 95).

${ }^{107}$ McKenzie (n 94).

${ }^{108}$ With one justice noting that 'the Act of 2009 requires to be construed in accordance with the Constitution. Clearly the Act of 2009 was part of governmental policy introduced to meet the very serious banking crisis within the State. However, this does not exempt it from the principles of the Constitution.' Dellway (n 97) 230.
} 
order. While space precludes an in-depth analysis two possible features of the Irish constitutional order might explain these developments: a strong executive and a weak economic and social rights culture.

On the one hand, Ireland's constitutional architecture and political culture has resulted in an exceptionally strong executive vis-à-vis the legislature. A fused executive-legislative in the lower house, an in-built government majority in the upper house, a budgetary process dominated by government, an especially strong whip-system and a weak independent parliamentary culture has resulted in an exceptional executive dominance. A special parliamentary procedure allowing the Government to 'guillotine' legislative debate allows the swift passage of legislation by government, which automatically holds a majority, and removes to some extent the need for emergency decree type legislation. The government already has a large scope for manoeuver within the legislative process and is relatively free from political constraints. There is therefore little need for the government to bypass ordinary legislative procedures. The judgment in Collins ${ }^{109}$ while careful to identify a role for Parliament, further illustrates the importance of the executive in budgetary matters and the discretion afforded it by the Constitution.

Secondly, in relation to the use of an emergency doctrine to justify infringements of fundamental rights it should be noted that Ireland's fundamental rights tradition is liberal in nature with a strong protection for classic rights of personal autonomy and property and a weakly developed Economic and Social Rights culture. ${ }^{110}$ While there have been some judicial pronouncements on the need to judicially enforce social rights, ${ }^{111}$ the Courts have been reluctant to endorse a set of judiciable socio-economic rights ${ }^{112}$ and social rights. ${ }^{113}$ This dichotomy is mirrored in the case of the Eurocrisis caselaw. The Courts have been reluctant to intervene to protect rights relating to pay and pensions in the FEMPI case law, while strongly upholding more classic procedural and due process rights in Dellway. ${ }^{114}$

\section{Conclusion}

The case studies evince that the concept of emergency is translated differently into national legal systems depending both on their legal traditions and the particular challenges faced by the countries. In Greece, Italy and Spain the already existing trend to the 'use and abuse' emergency legislative instruments has been magnified amidst pressures for structural reform of the administration and of the labour market. In Ireland, on the contrary, a traditionally strong executive and a weak culture of economic and social rights have paved the way for the approval of public sector cuts and the recapitalisation of the banking sector without generating much controversy. Often judicial reactions to Euro-crisis law have been lenient, mirroring the language of emergency used by the executive. ${ }^{115}$ Two exceptions emerge from the present study: in Italy, the Corte Constituzionale has invalidated the Decree-laws suppressing most of the competences of the Provinces ${ }^{116}$ (although the Corte did so on

\footnotetext{
${ }^{109}$ Bunreacht na hÉireann (n 95).

${ }^{110}$ See the contribution of Aoife Nolan in Claire Kilpatrick and Bruno de Witte, Social Rights in Times of Crisis in the Eurozone: the Role of Fundamental Rights (EUI Working Papers, LAW 2014/05, Department of Law, 2014) at 30.

${ }^{111}$ See TD v Minister for Educartion [2000] 3 IR 62 High Court, later over-turned in TD v Minister for Education [2001] 4 IR 259 Supreme Court.

${ }^{112}$ Sinnot v Minister for Education and the Attorney General [2001] 7 JIC 1201 Supreme Court.

${ }^{113}$ See the contribution of Aoife Nolan in Kilpatrick and de Witte, Social Rights in Times of Crisis in the Eurozone: the Role of Fundamental Rights (n 110).

${ }^{114}$ Dellway (n 97).

115 The situation has been changing in Greece, though. Cf. the Greek report, Section X, para X.9 'Case Law Implementing Measures'.

${ }^{116}$ Decree $2010 / 2011$ and 95/2012
} 
merely formal grounds), and in Ireland the Supreme Court has bluntly upheld the right to a fair proceeding within the 'toxic asset' removal programme ${ }^{117}$ (yet, this intervention has been exceptional and, as explained above, restricted to the defence of traditional liberal rights).

What all the manifestations of emergency explored might have in common is, paradoxically, their contrast with 'emergency' as it has been long conceived in the classic literature. The Roman constitution foresaw the appointment of a dictator with great executive powers in case of emergency, but precluded him from effecting perpetual changes beyond the crisis itself ${ }^{118}$. This dimension of temporariness is entirely absent the response of the various governments to the Eurocrisis. Yet they continue to invoke the context of emergency as a justification for their actions. Understandably, no European constituent could imagine a nation-threatening financial crisis and regulate it accordingly. Yet what seems striking is the ease with which the four Member States analysed here have used the narrative of economic emergency to effect reforms that are far from temporary and that will remain in the legal system even in case of an eventual economic recovery.

Further research on national manifestations of emergency in the aftermath of the Eurozone crisis could help elucidate whether executives and judiciaries have surrendered to the narrative of "necessity for bare survival', but also to what extent this narrative is leading to a profound (even abusive) modification of their constitutional setting. Such a research could expose the real implications of the euro crisis for constitutional law, and could perhaps be taken into account in order to avoid furtive institutional reforms in future crises.

\footnotetext{
${ }^{117}$ Dellway, see footnote no. 96 and accompanying text.

${ }^{118}$ Corte Costituzionale 19 luglio 2013, n. 220, see footnote no. 49 and accompanying text.
} 
